\title{
In Situ Production of Copper Oxide Nanoparticles in a Binary Molten Salt for Concentrated Solar Power Plant Applications
}

\author{
Mathieu Lasfargues ${ }^{1,2, *}$, Graham Stead ${ }^{1}$, Muhammad Amjad ${ }^{1}$, Yulong Ding ${ }^{2}$ and \\ Dongsheng Wen 1,3 ,* \\ 1 School of Chemical and Process Engineering, University of Leeds, Leeds LS2 9JT, UK; \\ g.stead1988@gmail.com (G.S.); pmmamj@leeds.ac.uk (M.A.) \\ 2 School of Chemical Engineering, University of Birmingham, Birmingham B15 2TT, UK; Y.Ding@bham.ac.uk \\ 3 School of Aeronautic Science and Engineering, Beihang University, Beijing 100191, China \\ * Correspondence: m.lasfargues@outlook.com (M.L.); d.wen@leeds.ac.uk (D.W.); Tel.: +44-113-3431299 (D.W.)
}

Academic Editor: Christof Schneider

Received: 5 April 2017; Accepted: 12 May 2017; Published: 19 May 2017

\begin{abstract}
Seeding nanoparticles in molten salts has been shown recently as a promising way to improve their thermo-physical properties. The prospect of such technology is of interest to both academic and industrial sectors in order to enhance the specific heat capacity of molten salt. The latter is used in concentrated solar power plants as both heat transfer fluid and sensible storage. This work explores the feasibility of producing and dispersing nanoparticles with a novel one pot synthesis method. Using such a method, $\mathrm{CuO}$ nanoparticles were produced in situ via the decomposition of copper sulphate pentahydrate in a $\mathrm{KNO}_{3}-\mathrm{NaNO}_{3}$ binary salt. Analyses of the results suggested preferential disposition of atoms around produced nanoparticles in the molten salt. Thermal characterization of the produced nano-salt suspension indicated the dependence of the specific heat enhancement on particle morphology and distribution within the salts.
\end{abstract}

Keywords: in-situ production; nanoparticles; molten salts; solar energy; specific heat capacity; CSP; concentrated solar power

\section{Introduction}

Molten salts have been considered as a promising heat transfer fluid (HTF) replacement for synthetic oil in concentrated solar power plants (CSP) and could as well be used for thermal energy storage materials in both renewable and conventional energy systems. Currently, the most utilized heat transfer fluid in CSP application is synthetic oil such as 'VP1 Therminol', which is a binary mixture of biphenyl and diphenyl oxide. However, its high purchasing price, low vapor pressure, toxicity to the environment and low maximum temperature $\left(390^{\circ} \mathrm{C}\right)$ are pushing industrial and academic researchers to look for alternative materials. Molten salts are the solution to this challenge; in fact, a binary mixture of sodium (60 wt. \%) and potassium nitrate (40 wt. \%), also dubbed 'Solar Salt' [1], has been the most used medium for this application. However, molten salts suffer the problem of low specific heat capacities $\left(c_{p}\right)$. Introducing nanoparticles into a salt to improve its thermo-physical property is an effective solution, which has been intensively studied in the last decade [2-6]. However, the dispersion of nanoparticles into molten salts to form a fairly homogeneous mixture is still a highly challenging process as the materials are in solid phase at temperatures below the melting point of the salt.

To resolve the problem, Shin and Banerjee (2010) dissolved a mixture of carbonate salts into deionized water containing $1.5 \%$ by mass of $\mathrm{SiO}_{2}$ nanoparticles of $1-20 \mathrm{~nm}^{2}$. The solution was 
sonicated for a couple of hours and then evaporated in a petri-dish, leading to the formation of crystalline structures of coarse and fine nature. The fine structure was proposed to be responsible for the experimentally observed enhancements of specific heat by $34 \%$ and $101 \%$ for the solid and liquid phase, respectively; whilst the coarse structure gave an increase by $20-24 \%$ (solid phase) and $73-75 \%$ (liquid phase). The change in the spatial arrangement of the nanoparticles was proposed by Shin and Banerjee (2010) for the alteration of ability to store energy.

There are several hypotheses attempting to explaining the enhancement of specific heat by nanoparticles, which cannot come from the nanoparticles themselves as the latter display low specific heat capacity (i.e., typically below $1.0 \mathrm{~J} /\left[\mathrm{g}^{*} \mathrm{~K}\right]$ ). Instead, the enhancement must come from the interaction between the nanoparticles and the salts, which has been partly demonstrated by Oh et al. (2005), who showed the formation of layers of aluminum atoms in liquid form at the solid interface of sapphire [7]. In a similar fashion, it is thought that the salt's ions formed nano-layers at the interface with nanoparticles such that the atoms at this particular boundary are constrained into a semi-solid structure [8]. This formation would not behave like a typical liquid. It is further hypothesized that the observed enhancement could be due to the partial incorporation of the enthalpy of fusion as a mean to explain this rise in $c_{p}$. Furthermore, the specific heat capacity of the nanoparticles themselves is enhanced when the overall size is reduced compared to their bulk counterparts, as described and tested by Wang et al. (2001, 2006) and Tan et al. (2009) [9-11]. Indeed, reducing the size of particles increases their specific surface area and the number of surface atoms exposed. The latter have far more freedom compared to atoms closer to the center, leading to a blue shift in wave number as observed by Wang et al. (2001), indicating a higher surface energy compared to bulk for $\mathrm{Al}_{2} \mathrm{O}_{3}$ when tested by FT-IR spectrophotometer [9]. Finally, the interfacial thermal resistance between the solid nanoparticles and the surrounding liquid could also be a mechanism for the storage of energy [12]. Whilst all of those cited mechanisms might play a part in the enhancement, the production of nano-layer seems to be the most involved player.

As summarized in Table 1, a number of publications have been made on the enhancement of specific heat of molten salts using nanoparticles [2-8,13-23]. However, most publications (Table 1-First 16 Rows) follow the same methodology of production with very little deviation [21,22]. These methodologies can be generally called 'two-step' methods, where nanoparticles were purchased or produced first, and then dispersed into a base salt. Indeed, whilst the dissolution of salt and the sonication of nanoparticles promote a good dispersion and homogeneity, the evaporation of water and eventual crystallization of the salt would lead to the production of heterogeneous structures (i.e., a mixture of coarse and fine structures). The energy required to evaporate the water in this production process as well as the price of nanoparticles themselves is going to render this technology far too expensive to be deemed viable.

A few other methods such as the physical dispersion of grinded powder [22] or in situ production of nanoparticles could be potential ways for scale up synthesis, as both techniques could be developed into a scalable one pot synthesis, which facilitates the industrialization of the process. Lasfargues et al. (2016) proposed a similar process whereby titanium oxysulphate was thermally degraded in a binary molten salt mixture to obtain $\mathrm{TiO}_{2}$ nanoparticles. In an analogous manner, but using a different substrate as well as different production methodology to the one in this paper, Yan et al. (2017) attempted the production of $\mathrm{CuO}$ nanoparticles via a high temperature decomposition of copper oxalate, and a moderate increase in $c_{p}$ was reported. In this paper, a novel one pot synthesis method is performed via an in situ production of copper oxide from copper sulphate pentahydrate in a binary salt to form nano-salts. Detailed characterization of the formed products, including the preferential disposition of atoms around nanoparticles and the specific heat properties, are conducted, as below. 
Table 1. First 16 Rows: Research papers using the dissolution, sonication and drying method to disperse the nanoparticles within the salt [2-8,13-23]. 17th Row: Dispersion of nanoparticles through the powder mixing method [22]. 18th Row: Production of nanoparticles within molten salt using a precursor [21].

\begin{tabular}{|c|c|c|c|c|c|c|c|c|}
\hline \multirow{2}{*}{ Author } & \multirow{2}{*}{ Nanoparticle } & \multicolumn{2}{|l|}{ Size } & \multirow{2}{*}{ Concentration } & \multirow{2}{*}{ Base Fluid(s) } & \multirow{2}{*}{$\begin{array}{l}\text { Measured Temperature } \\
\text { in DSC }\left({ }^{\circ} \mathrm{C}\right)\end{array}$} & \multirow{2}{*}{$c_{p}$ Enhancement $(\%)$} & \multirow{2}{*}{ Ref } \\
\hline & & Diameter & Length & & & & & \\
\hline $\begin{array}{c}\text { Shin and Banerjee-November } \\
2010 \text { (IJSCS) }\end{array}$ & $\mathrm{SiO}_{2}$ & $1-20 \mathrm{~nm}$ & - & $1.5 \mathrm{wt.} \%$ & $\begin{array}{r}\mathrm{Li}_{2} \mathrm{CO}_{3}+\mathrm{K}_{2} \mathrm{CO}_{3} \\
\text { (62:38 molar ratio) }\end{array}$ & $350-550$ & $\begin{array}{l}\text { Solid Phase: } 20-42 \%, \\
\text { Liquid Phase: } 73-101 \% \\
\end{array}$ & [2] \\
\hline $\begin{array}{l}\text { Shin and Banerjee- November } \\
2010 \text { (Journal of Heat Transfer) }\end{array}$ & $\mathrm{SiO}_{2}$ & $20-30 \mathrm{~nm}$ & - & $1.0 \mathrm{wt.} \%$ & $\mathrm{BaCl}_{2}+\mathrm{NaCl}+\mathrm{CaCl}_{2}+\mathrm{LiCl}$ & $495-555$ & Liquid Phase: $14.5 \%$ & [3] \\
\hline $\begin{array}{c}\text { Shin and Banerjee-February } \\
2011 \text { (IJHMT) }\end{array}$ & $\mathrm{SiO}_{2}$ & $10 \mathrm{~nm}$ & - & $1.0 \mathrm{wt.} \%$ & $\mathrm{Li}_{2} \mathrm{CO}_{3}+\mathrm{K}_{2} \mathrm{CO}_{3}(62: 38$ molar ratio $)$ & $525-555$ & Liquid Phase: $19-24 \%$ & [4] \\
\hline $\begin{array}{l}\text { Tiznobaik and Shin-November } \\
2012 \text { (IJHMT) }\end{array}$ & $\mathrm{SiO}_{2}$ & $5,10,30$ and $60 \mathrm{~nm}$ & - & $1.0 \mathrm{wt.} \%$ & $\begin{array}{c}\mathrm{Li}_{2} \mathrm{CO}_{3}+\mathrm{K}_{2} \mathrm{CO}_{3} \\
\text { (62:38 molar ratio) }\end{array}$ & $150-550$ & $\begin{array}{l}\text { Solid Phase: } 23-28 \% \text {, } \\
\text { Liquid Phase: } 22-26 \%\end{array}$ & [6] \\
\hline $\begin{array}{l}\text { Shin and Banerjee-February } \\
2013 \text { (Journal of Heat Transfer) }\end{array}$ & $\mathrm{SiO}_{2}$ & $2-20 \mathrm{~nm}$ & - & $1.5 \%$ wt. $\%$ & $\begin{array}{l}\mathrm{Li}_{2} \mathrm{CO}_{3}+\mathrm{K}_{2} \mathrm{CO}_{3} \\
\text { (62:38 molar ratio) }\end{array}$ & $150-560$ & $\begin{array}{c}\text { Solid Phase: } 38-54 \%, \\
\text { Liquid Phase: } 118-124 \%\end{array}$ & [17] \\
\hline $\begin{array}{l}\text { Dudda and Shin-February } 2013 \\
\text { (IJTS) }\end{array}$ & $\mathrm{SiO}_{2}$ & $5,10,30$ and $60 \mathrm{~nm}$ & - & 1.0 wt. $\%$ & $\begin{array}{c}\mathrm{NaNO}_{3}+\mathrm{KNO}_{3} \\
\text { (60:40 weight \% ratio) }\end{array}$ & $150-450$ & $\begin{array}{l}\text { Solid Phase: } 3-10 \% \\
\text { Liquid Phase: } 8-24 \%\end{array}$ & [14] \\
\hline $\begin{array}{c}\text { Ho and Pan—October } 2013 \\
\text { (IJHMT) }\end{array}$ & $\mathrm{Al}_{2} \mathrm{O}_{3}$ & $<50 \mathrm{~nm}$ & - & $\begin{array}{l}0.016 \text { wt. } \%, 0.0625 \text { wt. } \%, \\
0.125 \text { wt. } \%, 0.25 \text { wt. } \%, 0.5 \\
\text { wt. } \%, 1 \text { wt. } \% \text { and } 2 \text { wt. } \%\end{array}$ & $\begin{array}{c}\mathrm{NaNO}_{3}+\mathrm{KNO}_{3}+\mathrm{NaNO}_{2} \\
(7: 53: 40 \text { weight } \% \text { ratio })\end{array}$ & $200-350$ & $\begin{array}{l}\text { Liquid Phase: } \\
-5.7-+19.9 \%\end{array}$ & [7] \\
\hline $\begin{array}{l}\text { Lu and Huang-2013 (Nanoscale } \\
\text { Research Letters) }\end{array}$ & $\mathrm{Al}_{2} \mathrm{O}_{3}$ & 13 and $90 \mathrm{~nm}$ & - & $\begin{array}{c}0.9 \text { vol. } \%, 2.7 \text { vol. } \% \text { and } \\
4.6 \text { vol. } \%\end{array}$ & $\begin{array}{c}\mathrm{NaNO}_{3}+\mathrm{KNO}_{3} \\
\text { (60:40 weight \% ratio) }\end{array}$ & $290-340$ & $\begin{array}{l}\text { Liquid Phase: negative } \\
\text { values }\end{array}$ & {$[5]$} \\
\hline $\begin{array}{l}\text { Chieruzzi, et al. } 2013 \text { (Nanoscale } \\
\text { Research Letters) }\end{array}$ & $\begin{array}{c}\mathrm{Al}_{2} \mathrm{O}_{3}, \mathrm{SiO}_{2} \\
\mathrm{SiO}_{2}-\mathrm{Al}_{2} \mathrm{O}_{3} \text {, and } \mathrm{TiO}_{2}\end{array}$ & $\begin{array}{l}13 \mathrm{~nm}, 7 \mathrm{~nm}, 2-200 \\
\mathrm{~nm} \text { and } 2 \mathrm{~nm}\end{array}$ & - & $\begin{array}{l}0.5 \text { wt. } \%, 1.0 \mathrm{wt} . \% \text { and } \\
1.5 \text { wt. } \%\end{array}$ & $\begin{array}{c}\mathrm{NaNO}_{3}+\mathrm{KNO}_{3} \\
\text { (60:40 weight \% ratio) }\end{array}$ & $155-295$ & $\begin{array}{l}\text { Solid Phase: }-17-+58 \% \text {, } \\
\text { Liquid Phase: }-20-+23 \%\end{array}$ & [15] \\
\hline $\begin{array}{c}\text { Liu, et al. } 2013 \text { (2nd IET } \\
\text { Renewable Power Generation) }\end{array}$ & MWCNTs, Au & $\mathrm{Au}(5 \mathrm{~nm}$ and $10 \mathrm{~nm})$ & - & $\begin{array}{l}\text { MWCNTs (0.5 wt. \%, } \\
1 \text { wt. \% and } 1.5 \text { wt. \%) }\end{array}$ & $\begin{array}{c}\mathrm{NaNO}_{3}+\mathrm{KNO}_{3} \\
\text { (60:40 weight \% ratio) }\end{array}$ & $370-420$ & $\begin{array}{l}\text { Liquid Phase: up to } \\
+100 \% \text { for MWCNTs and } \\
+220 \% \text { for Au }\end{array}$ & [13] \\
\hline $\begin{array}{l}\text { Jo and Banerjee-May } 2014 \\
\text { (ActaMaterialia) }\end{array}$ & Graphite & - & $50 \mathrm{~nm}$ & $0.1 \mathrm{wt} . \%$ & $\begin{array}{c}\mathrm{Li}_{2} \mathrm{CO}_{3}+\mathrm{K}_{2} \mathrm{CO}_{3} \\
\text { (74.6:25.4-62:38-34:64 molar ratios) }\end{array}$ & $\begin{array}{l}\text { Solid Phase: } 250 \text { and } 400, \\
\text { Liquid Phase: } 525 \\
\text { and } 555\end{array}$ & $\begin{array}{l}\text { Solid Phase: } 28-40 \% \text {, } \\
\text { Liquid Phase: } 17-57 \%\end{array}$ & {$[8]$} \\
\hline $\begin{array}{l}\text { Seo and Shin-September } 2014 \\
\text { (Micro and Nano Letters) }\end{array}$ & $\mathrm{SiO}_{2}$ & $60 \mathrm{~nm}$ & - & 1.0 wt. $\%$ & $\begin{array}{c}\mathrm{LiNO}_{3}+\mathrm{NaNO}_{3}+\mathrm{KNO}_{3} \\
(38: 15: 47 \text { molar ratio) }\end{array}$ & $150-400$ & $\begin{array}{l}\text { Solid and Liquid } \\
\text { Phase: } 13 \%\end{array}$ & [18] \\
\hline $\begin{array}{l}\text { Andreu-Cabedo, et al. } 2014 \\
\text { (Nanoscale Research Letters) }\end{array}$ & $\mathrm{SiO}_{2}$ & $12 \mathrm{~nm}$ & - & $\begin{array}{l}0.5 \text { wt. } \%, 1.0 \text { wt. } \% \text {, } \\
1.5 \text { wt. } \%, 2.0 \text { wt. } \%\end{array}$ & $\begin{array}{c}\mathrm{NaNO}_{3}+\mathrm{KNO}_{3} \\
\text { (60:40 weight \% ratio) }\end{array}$ & $250-450$ & Liquid Phase: $3-25 \%$ & [2] \\
\hline $\begin{array}{l}\text { Jo and Banerjee-September } \\
2015 \text { (Journal of Heat Transfer) }\end{array}$ & MWCNTs & $10-30 \mathrm{~nm}$ & $1.5 \mu \mathrm{m}$ & $\begin{array}{l}0.1 \text { wt. } \%, 0.5 \text { wt. } \% \text {, } \\
1 \text { wt. } \% \text { and } 5 \text { wt. } \%\end{array}$ & $\begin{array}{l}\mathrm{Li}_{2} \mathrm{CO}_{3}+\mathrm{K}_{2} \mathrm{CO}_{3} \\
\text { (62:38 molar ratio) }\end{array}$ & $\begin{array}{l}\text { Solid Phase: } 250 \text { and } 400 \text {, } \\
\text { Liquid Phase: } 525-555\end{array}$ & $\begin{array}{l}\text { Solid Phase: } 12 \%, \\
\text { Liquid Phase: } 15 \%\end{array}$ & [16] \\
\hline Schuller, et al. 2015 (IJTS) & $\mathrm{Al}_{2} \mathrm{O}_{3}$ & $40 \mathrm{~nm}$ & - & $\begin{array}{c}0.125 \%, 0.25 \%, 0.5 \%, 0.75 \\
1 \%, 1.5 \% \text { and } 2 \% \text { (nominal } \\
\text { mass fraction) }\end{array}$ & $\begin{array}{c}\mathrm{NaNO}_{3}+\mathrm{KNO}_{3} \\
\text { (60:40 weight \% ratio) }\end{array}$ & $250-450$ & Liquid Phase: up to $31 \%$ & [19] \\
\hline $\begin{array}{l}\text { Lasfargues, et al_-June } 2015 \\
\text { (MDPI-nanomaterials) }\end{array}$ & $\mathrm{CuO}, \mathrm{TiO}_{2}$ & $\begin{array}{c}\mathrm{CuO}-29 \mathrm{~nm} \text { and } \\
\mathrm{TiO}_{2}-34 \mathrm{~nm}\end{array}$ & - & $\begin{array}{c}0.1 \text { wt. } \%, 0.5 \text { wt. } \%, \\
1 \text { wt. } \% \text { and } 1.5 \text { wt. } \%\end{array}$ & $\begin{array}{c}\mathrm{NaNO}_{3}+\mathrm{KNO}_{3} \\
\text { (60:40 weight \% ratio) }\end{array}$ & $250-450$ & Liquid Phase: up to $10 \%$ & [22] \\
\hline $\begin{array}{l}\text { Lasfargues, et al.-May } 2016 \\
\text { (Springer-J Nanopart Res) }\end{array}$ & $\mathrm{TiO}_{2}$ & $\mathrm{TiO}_{2}-16 \mathrm{~nm}$ & - & $\begin{array}{c}1 \text { wt. } \%, 2 \text { wt. } \% \text { and } \\
3 \text { wt. } \%\end{array}$ & $\begin{array}{c}\mathrm{NaNO}_{3}+\mathrm{KNO}_{3} \\
\text { (60:40 weight \% ratio) }\end{array}$ & $250-450$ & Liquid Phase: $\max 7.5 \%$ & [21] \\
\hline
\end{tabular}




\section{Methodology}

\subsection{Sample Preparation}

Sodium nitrate (Sigma Aldrich, Gillingham, UK, $\geq 99.0 \%$ ), potassium nitrate (VWR Prolabo Chemicals, Lutterworth, UK, 99.9\%) and copper sulphate pentahydrate (Fluka Analytica, Gillingham, UK, $\geq 99.0 \%$ ) were purchased and prepared through two different processes. The first method is called powder mixing (PM), which involved the grinding of the relevant powder ratios (Table 2) together in a pestle and mortar before transferring the sample into a $20-\mathrm{mL}$ disposable aluminum crucible. The second method is called wet mixing (WM), in which the salt mixture was dissolved into $500 \mathrm{~mL}$ of deionized water before crystallization on a heating plate. The aluminum container was then inserted into a furnace at $450{ }^{\circ} \mathrm{C}$ for $30 \mathrm{~min}$. After this period of time, the sample was removed and placed at room temperature to crystallize. The solid mixture was crushed in a pestle and mortar to obtain a powdered mixture, which was characterized via DSC, SEM and EDX.

Table 2. Weight of samples used for the production of the different concentration of copper oxide nanoparticles in molten salt (the ratio of $\mathrm{NaNO}_{3}$ to $\mathrm{KNO}_{3}$ is always 60/40).

\begin{tabular}{|c|c|c|c|c|c|}
\hline $\mathrm{NaNO}_{3}(\mathrm{~g})$ & $\mathrm{KNO}_{3}(\mathrm{~g})$ & $\begin{array}{c}\mathrm{CuSO}_{4} \cdot 5 \mathrm{H}_{2} \mathrm{O} \\
\text { (wt. \%) }\end{array}$ & $\underset{(\mathrm{g})}{\mathrm{CuSO}_{4} .5 \mathrm{H}_{2} \mathrm{O}}$ & $\begin{array}{c}\text { Total Weight } \\
\text { (g) }\end{array}$ & $\begin{array}{c}\text { Theoretical CuO (wt. \%) } \\
\text { after Production of } \\
\text { Nanoparticles }\end{array}$ \\
\hline 2.9925 & 1.995 & 0.25 & 0.0125 & 5 & 0.08 \\
\hline 2.985 & 1.99 & 0.5 & 0.025 & 5 & 0.16 \\
\hline 2.9775 & 1.985 & 0.75 & 0.0375 & 5 & 0.24 \\
\hline 2.97 & 1.98 & 1 & 0.05 & 5 & 0.32 \\
\hline 2.91 & 1.94 & 3 & 0.15 & 5 & 0.98 \\
\hline 2.85 & 1.9 & 5 & 0.25 & 5 & 1.65 \\
\hline
\end{tabular}

(Molar mass of CuO-79.55 g/mol, molar mass of $\mathrm{CuSO}_{4} \cdot 5 \mathrm{H}_{2} \mathrm{O}-249.69 \mathrm{~g} / \mathrm{mol}$. Reaction going to completion $=$ $79.55 / 249.69 \times 100=31.86 \%$. For 1 wt. $\%$ of $\mathrm{CuSO}_{4} .5 \mathrm{H}_{2} \mathrm{O}$, the theoretical $\mathrm{CuO}$ in wt. $\%$ is equal to the following: $(31.86 \times 0.05 / 100) /(31.86 \times 0.05 / 100+2.97+1.98)=0.32)$.

\subsubsection{DSC}

The samples $(30,000-35,000 \mathrm{mg})$ were inserted into 30- $\mu \mathrm{L}$ platinum crucibles and repeatedly melted and frozen (an isothermal of $150{ }^{\circ} \mathrm{C}$ for $2 \mathrm{~min}$ with a dynamic ramp to $300{ }^{\circ} \mathrm{C}$ at $10{ }^{\circ} \mathrm{C} / \mathrm{min}$, followed by an isothermal of $2 \mathrm{~min}$ at $300{ }^{\circ} \mathrm{C}$, ramping down to $150{ }^{\circ} \mathrm{C}$ at $10^{\circ} \mathrm{C} / \mathrm{min}$, with a final isotherm of $2 \mathrm{~min}$; cycle repeated three times) before carrying out the $\mathrm{c}_{\mathrm{p}}$ measurements. The thermal cycle employed for this latter test was an isothermal at $250^{\circ} \mathrm{C}$ for $5 \mathrm{~min}$, followed by a dynamic ramp to $450{ }^{\circ} \mathrm{C}$ at $40{ }^{\circ} \mathrm{C} / \mathrm{min}$ with another isothermal of $5 \mathrm{~min}$ at $450{ }^{\circ} \mathrm{C}$. A sapphire standard $(27,737 \mathrm{mg})$ was used to measure the specific heat capacity. Three samples, each tested three times, were measured in order to obtain the standard deviation used in Figures 5 and 6.

\subsubsection{SEM and EDX}

The morphological and elemental analyses of the samples were achieved through the use of a field emission SEM (Hitachi SU8230). The samples were mounted on 12-mm aluminum stub. The coating was formed using a high-resolution sputter coater with a mixture of platinum/palladium (80/20).

\section{Results and Discussion}

After the removal of the aluminum holder containing the sample from the $450{ }^{\circ} \mathrm{C}$ furnace, it was cooled down to room temperature on a stainless steel sheet (Figure 1A). A visual inspection of the molten salt showed that the increase in concentration of the copper sulphate pentahydrate in the salt mixture led to darker shade of solid, due presumably to an increased concentration of copper oxide particles produced. Furthermore, it was observed that the particles in question would settle on the bottom as the underside of the salt crystal always displayed a darker color than the top part (Figure 1B,C). 


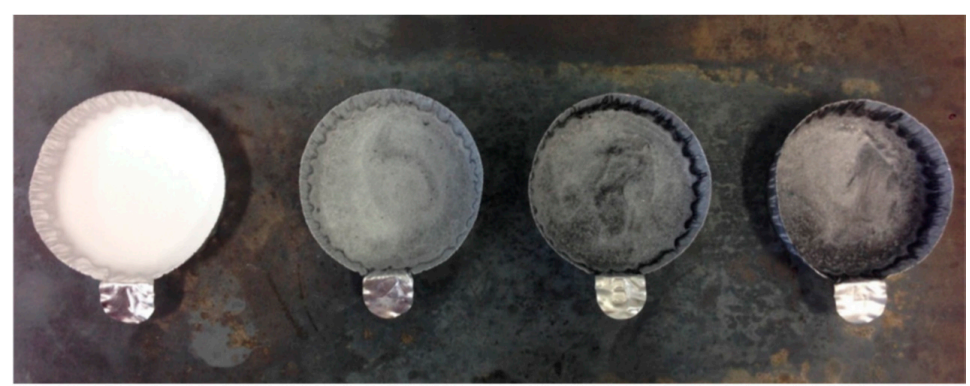

A

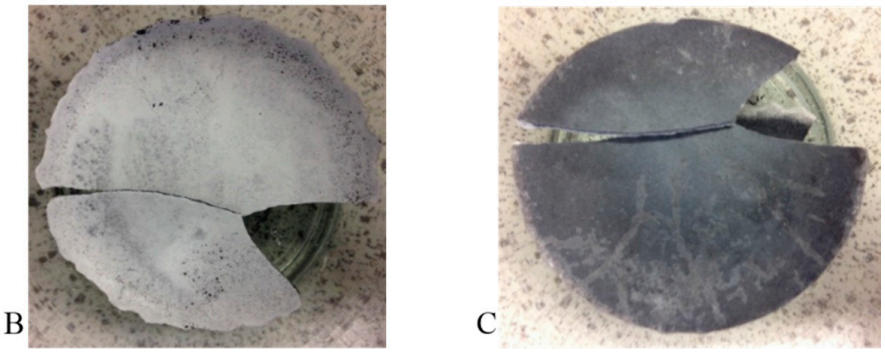

Figure 1. (A) Picture of the crucibles taken out of the furnace and left to crystallize on a sheet of stainless steel. The left crucible shows a sample of pure salt (white) $\left(60 / 40\right.$ ratio- $\left.\mathrm{NaNO}_{3} / \mathrm{KNO}_{3}\right)$ whilst the next three samples (left to right) contain increasing concentrations of copper oxide calculated to be $0.32,0.98$ and 1.65 wt. \%; (B) Top view of 0.98 wt. \% CuO samples; (C) View of the underside of 0.98 wt. \% $\mathrm{CuO}$ solid salt mixture.

Based on the stoichiometry of the reaction, the following steps take place, whereby the salt first becomes dehydrated, leading to the total removal of water, and then sulphur trioxide is released, leaving behind copper oxide (dark residue).

$$
\begin{gathered}
\mathrm{Cu}(\mathrm{II}) \mathrm{SO}_{4} \cdot 5 \mathrm{H}_{2} \mathrm{O}+\text { Heat } \rightarrow \mathrm{Cu}(\mathrm{II}) \mathrm{SO}_{4}+5 \mathrm{H}_{2} \mathrm{O} \\
\mathrm{Cu}(\mathrm{II}) \mathrm{SO}_{4}+\text { Heat } \rightarrow \mathrm{CuO}+\mathrm{SO}_{3}
\end{gathered}
$$

It has been shown by Harris and Kalbus (1979) that the decomposition of copper sulphate pentahydrate to copper oxide requires a temperature of $1000{ }^{\circ} \mathrm{C}$ for the removal of the sulphur trioxide [24]. However, our analysis carried out by EDX did not show any sign of sulphur within the sample (Figure 2). Only nitrogen, oxygen, sodium, potassium and copper (Figure 2: EDX spectrum) were picked up, implying the formation of copper oxide only, as the sodium and potassium nitrate would have been unlikely to react with the copper sulphate pentahydrate. Indeed, from the EDX spectrum (Figure 2), we can estimate the stoichiometry of each compound with the ratio of sodium nitrate to potassium nitrate staying at $6 / 4$, implying no reaction on its part, whilst the percentage of copper to oxygen is roughly 1 to 1 .

For the EDX analysis, copper, oxygen, potassium and sodium were investigated, as previous literature $[8,21]$ pointed out a preferential disposition of atoms around nanoparticles. Indeed, when potassium and sodium are placed on top of one another, it can be seen that the sodium atoms are less concentrated around the formed copper oxide particles (Figure 3). A similar observation has been described by Jo and Banerjee (2014) in their molecular dynamic (MD) model, and has also been shown by Lasfargues et al. (2016), with the production of titanium oxide nanoparticles using a similar technique. However, we show here experimentally that such a preferential deposition phenomenon can indeed happen. This phenomenon could be explained by the extra shell of electrons available in the potassium atoms, which shields the atoms more effectively from its nucleus, therefore allowing a greater interaction with the particles produced compared to the sodium atoms. The MD simulation of Jo and Banerjee (2014) also revealed greater adhesion forces between potassium ions and graphite compared with that of lithium [8], which further supports our observation. 

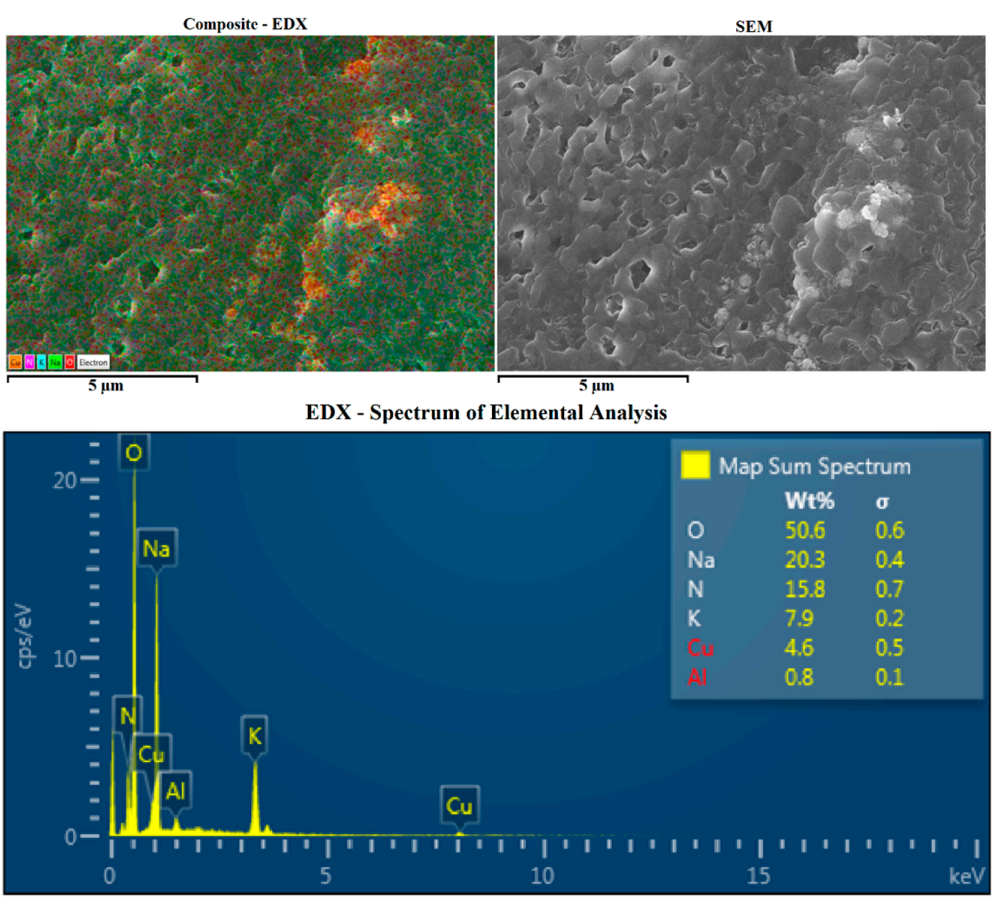

Figure 2. EDX Analysis of salt mixture $\left(60 \% \mathrm{NaNO}_{3}\right.$ and $\left.40 \% \mathrm{KNO}_{3}\right)$ with 1.65 wt. \% $\mathrm{CuO}$. The composite picture is an overlay of the SEM and the elemental analysis of the sample. The presence of aluminum come from the SEM stub.

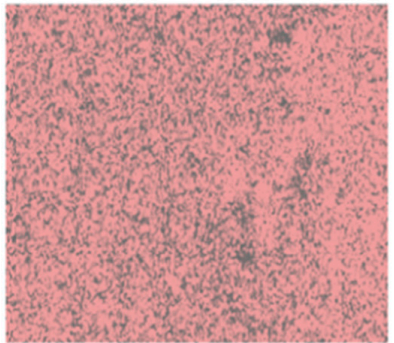

Potassium

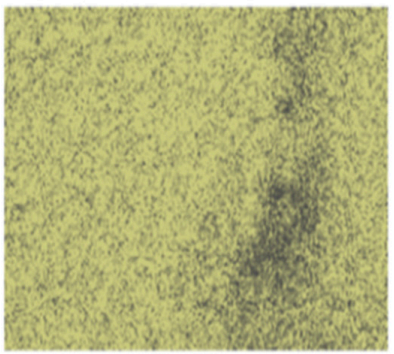

Sodium

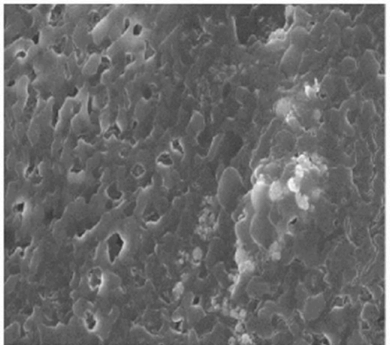

SEM

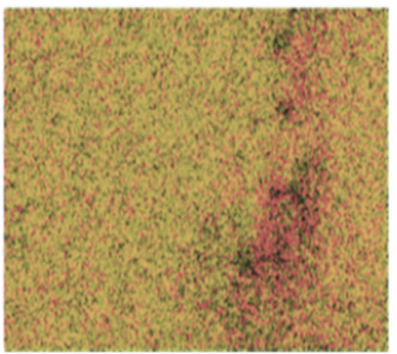

$\mathbf{K}+\mathbf{S}$ overlay

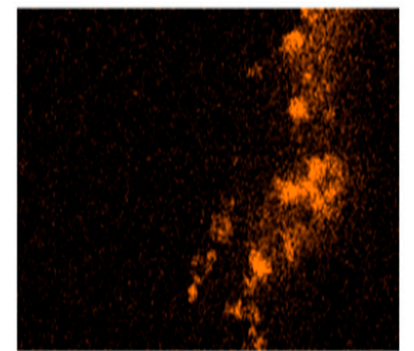

Copper

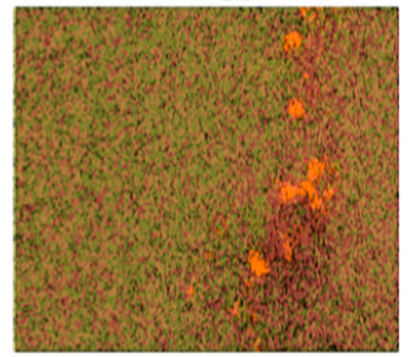

$\mathbf{K}+\mathbf{S}+\mathbf{C u}$ overlay

Figure 3. EDX mapping of potassium (red), sodium (yellow) and copper (orange) with several overlays to show the distribution of atoms.

The SEM analysis showed that the wet mixing method provided particles of a smaller size within the nanometer range, although the latter were heavily aggregated. Similarly, the powder mixing process led to the production of far larger particles of copper oxide with heterogeneous size and shape (Figure 4). Although the production process has been achieved and copper oxide nanoparticles have been successfully produced, the problem of aggregation still need to be resolved (Figure 4). The use of a dynamic process (high or low shear mixing/sonication) to reduce the agglomeration of these 
formed copper oxide nanoparticles in the wet mixing method could be employed. However, at these temperatures, it is likely that specific equipment would need to be built. Regarding the powder mixing process, the use of a blender rather than a pestle and mortar would provide better dispersion and homogenization of the mixture prior to the heating process.
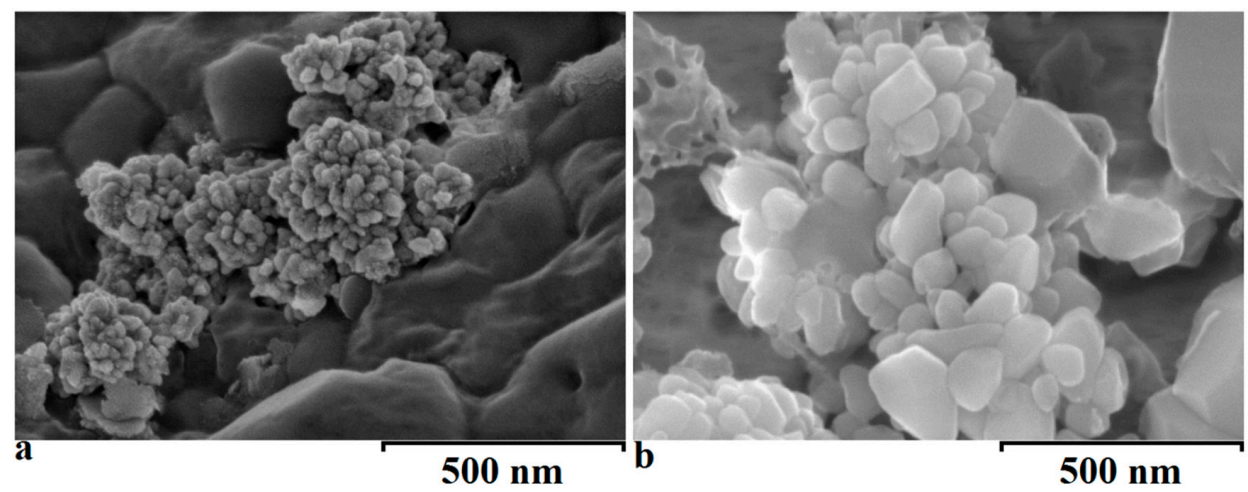

Figure 4. SEM images of copper oxide particles produced either through (a) wet mixing process or (b) powder mixing process. Magnification is $100.00 \mathrm{k}$.

The DSC measurement shows that the preparation method can affect the specific heat significantly, which is closely related to the particle morphology and distribution in the molten salt. These heavily aggregated particles impeded the specific heat capacity and did not cause any significant increase (Figure 5). It is hypothesized that for relatively well-dispersed particles, such as $0.75 \mathrm{wt}$. \% $\mathrm{CuO}$ produced through PM (Figure 6), a good increase in the specific heat $\left(5.6 \%\right.$ at $320{ }^{\circ} \mathrm{C}$ to 7.4 at $440{ }^{\circ} \mathrm{C}$-Figure 6) was observed. It is clear that the production of nanoparticles affects the $c_{p}$ value of the molten salt and, looking only at the average $c_{p}$ value and discarding the error bars, it can be seen that the powder method seems more effective at enhancing this property. Finding a way to better disperse the copper sulphate pentahydrate during the production process would directly impact the $c_{p}$ value. The enhancement seen with $0.75 \mathrm{wt}$. \% $\mathrm{CuO}$ through powder mixing is likely to be caused by the nano-layering effect, whereby ions would be constrained into a semi-solid structure at the interface with the solid $\mathrm{CuO}$. It is hypothesized that the aggregation of $\mathrm{CuO}$ would prevent the formation of such a semi-solid structure, leading to no or little enhancement of the specific heat capacity.
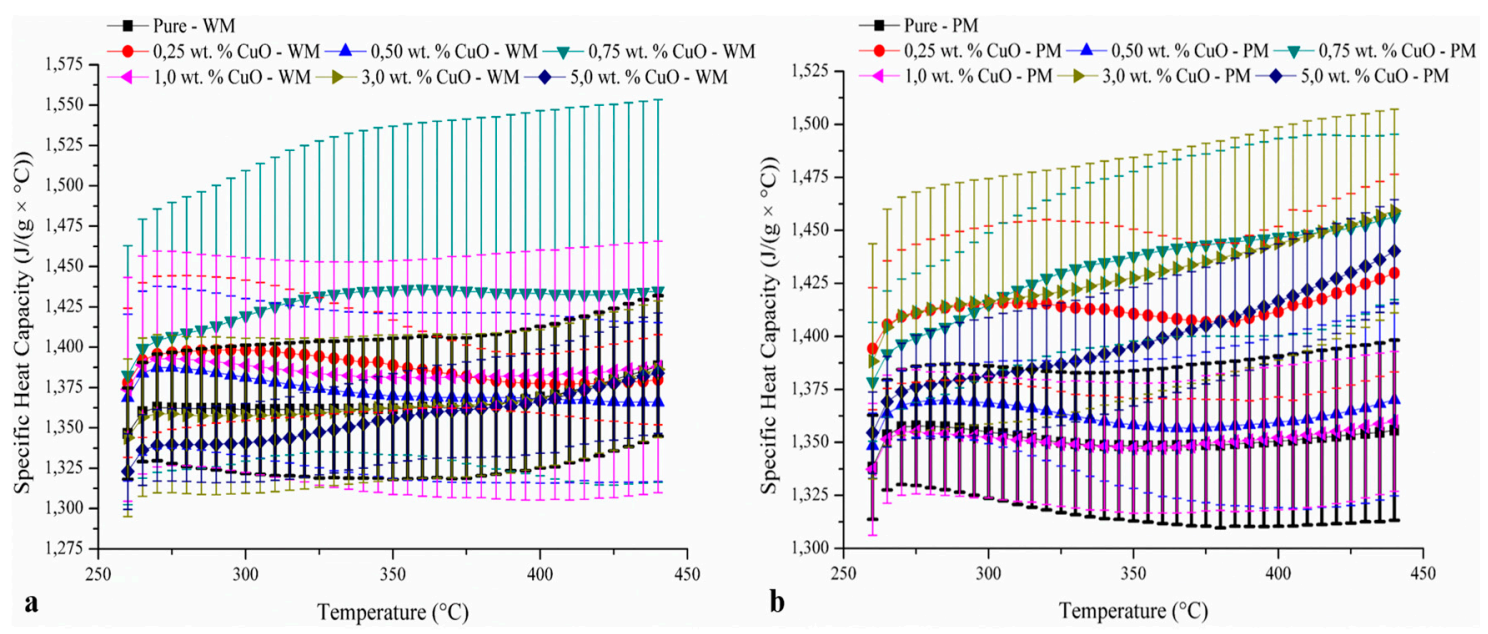

Figure 5. Specific heat capacity of the different ratios of salt tested using both the wet mixing (a) and the powder mixing (b) methods. 


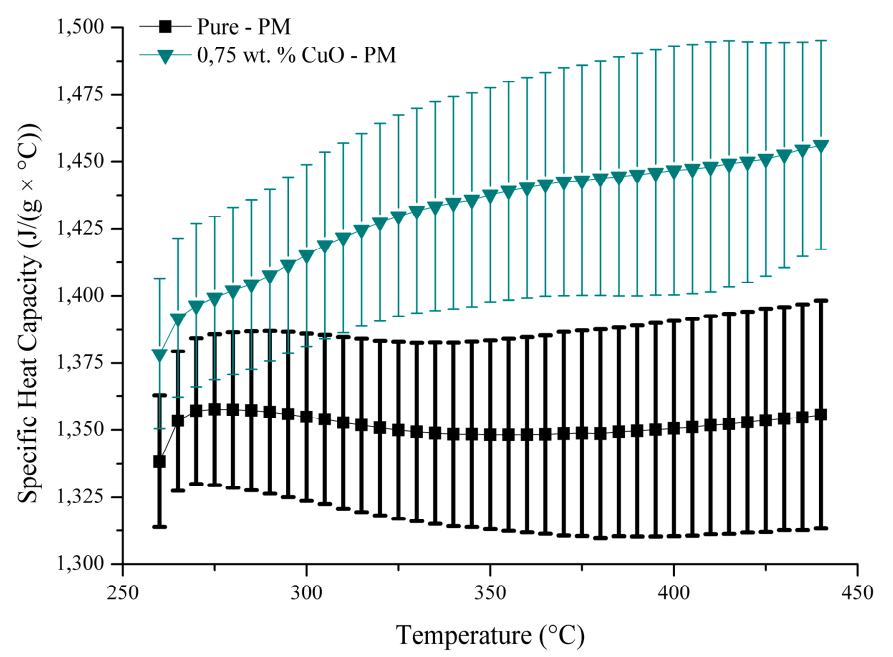

Figure 6. Specific heat capacity of the normal binary salt mixture against the enhanced mixture with 0.75 wt. \% $\mathrm{CuO}$ using the powder mixing method.

Such results were in line with the literature data, which showed that the effective specific heat could be higher or lower than the base salt, depending on particle morphology. Other parameters, such as melting temperature, showed a slight decreasing trend with the increase of the copper oxide concentration, whilst the enthalpy of fusion varied only slightly (Table 3). The decrease in melting temperature could be explained by an increase in entropy due to the presence of copper oxide altering the crystal formation in the melting and crystallization processes.

Table 3. Melting and enthalpy of the different tested ratios of salt + nanoparticles.

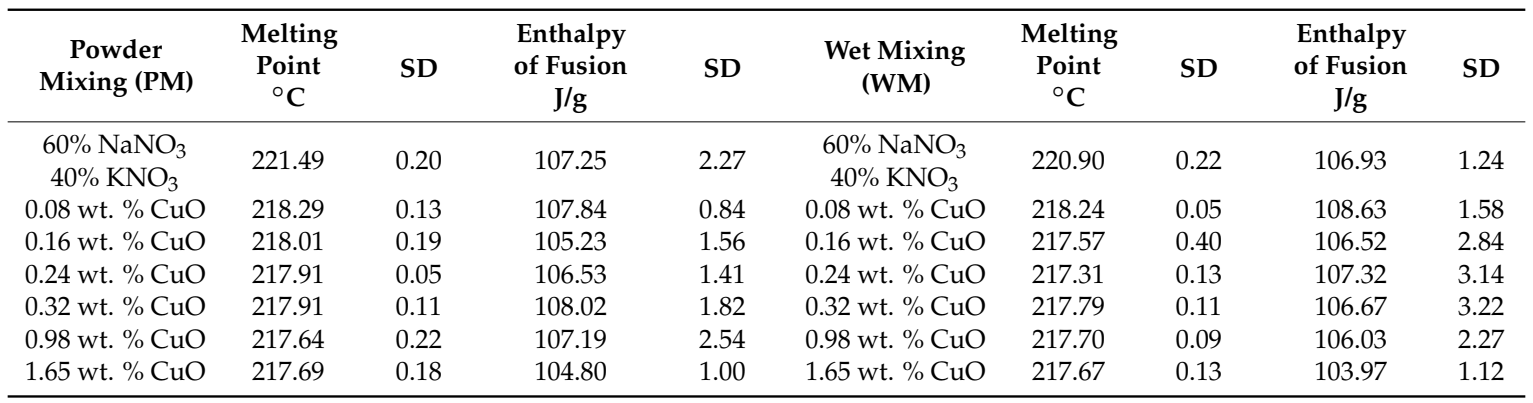

\section{Conclusions}

This paper shows the potential of using feedstock copper sulphate pentahydrate to produce copper oxide nanoparticles within a binary molten salt phase of a $60 \%$ sodium nitrate and $40 \%$ potassium nitrate environment. The results showed the preferential disposition of atoms around produced nanoparticles and different levels of specific heat enhancement, depending on the particle morphology and distribution inside the molten salts.

Most of the samples did not show a significant increase in $c_{p}$ compared to the base salt. However, when $0.75 \mathrm{wt}$. \% of copper sulfate pentahydrate was added to the molten salt, a significant increase in $\mathrm{c}_{\mathrm{p}}$ was achieved between $325^{\circ} \mathrm{C}$ and $440{ }^{\circ} \mathrm{C}$.

Whilst it is true that well-controlled nanoparticle production was not fully achieved for all the samples, i.e., the one pot reaction rendered heterogeneous particle sizes and the formation of aggregates. This type of process could be further refined and optimized for the economical production of nanoparticle dispersions in molten salts, promoting their applications in solar power plants as effective heat transfer fluids and/or storage materials. 
Acknowledgments: Financial support was provided by EPSRC EP/L014211/1 (Next generation grid scale thermal energy storage technologies), EPSRC EP/K002252/1 and European Research Council ERC-2014-CoG (Project Ref: 648375).

Author Contributions: Mathieu Lasfargues wrote the draft manuscript and carried out the SEM and EDX characterization. Graham Stead did the sample production and the DSC experiments, supported by Muhammad Amjad and Mathieu Lasfargues. Dongsheng Wen supervised the work and is responsible for the content of the manuscript.

Conflicts of Interest: The authors declare no conflict of interest.

\section{References}

1. Medrano, M.; Gil, A.; Martorell, I.; Potau, X.; Cabeza, L.F. State of the art on high-temperature thermal energy storage for power generation. Part 2-Case studies. Renew. Sustain. Energy Rev. 2010, 14, 56-72. [CrossRef]

2. Shin, D.; Banerjee, D. Effects of silica nanoparticles on enhancing the specific heat capacity of carbonate salt eutectic (work in progress). Int. J. Struct. Chang. SOLIDS 2010, 2, 25-31.

3. Shin, D.; Banerjee, D. Enhanced Specific Heat of Silica Nanofluid. J. Heat Transf. 2010, 133, 024501. [CrossRef]

4. Shin, D.; Banerjee, D. Enhancement of specific heat capacity of high-temperature silica-nanofluids synthesized in alkali chloride salt eutectics for solar thermal-energy storage applications. Int. J. Heat Mass Transf. 2011, 54, 1064-1070. [CrossRef]

5. Lu, M.-C.; Huang, C.-H. Specific heat capacity of molten salt-based alumina nanofluid. Nanoscale Res. Lett. 2013, 8, 292. [CrossRef] [PubMed]

6. Tiznobaik, H.; Shin, D. Enhanced specific heat capacity of high-temperature molten salt-based nanofluids. Int. J. Heat Mass Transf. 2013, 57, 542-548. [CrossRef]

7. Ho, M.X.; Pan, C. Optimal concentration of alumina nanoparticles in molten Hitec salt to maximize its specific heat capacity. Int. J. Heat Mass Transf. 2014, 70, 174-184. [CrossRef]

8. Jo, B.; Banerjee, D. Enhanced specific heat capacity of molten salt-based nanomaterials: Effects of nanoparticle dispersion and solvent material. Acta Mater. 2014, 75, 80-91. [CrossRef]

9. Wang, L.; Tan, Z.C.; Meng, S.G.; Liang, D.B.; Li, G.G. Enhancement of molar heat capacity of nanostructured $\mathrm{Al}_{2} \mathrm{O}_{3}$. J. Nanoparticle Res. 2001, 3, 483-487. [CrossRef]

10. Wang, B.-X.; Zhou, L.-P.; Peng, X.-F. Surface and Size Effects on the Specific Heat Capacity of Nanoparticles. Int. J. Thermophys. 2006, 27, 139-151. [CrossRef]

11. Tan, Z.-C.; Wang, L.; Shi, Q. Study of heat capacity enhancement in some nanostructured materials. Pure Appl. Chem. 2009, 81, 1871-1880. [CrossRef]

12. Xue, L.; Keblinski, P.; Phillpot, S.R.; Choi, S.U.-S.; Eastman, J.A. Effect of liquid layering at the liquid-solid interface on thermal transport. Int. J. Heat Mass Transf. 2004, 47, 4277-4284. [CrossRef]

13. Liu, S.; Wu, D.; Liu, J.; Nian, Y.; Qiu, P. Development of a novel molten-salt filled with nanoparticles for concentration solar plants. In Proceedings of the 2nd IET Renewable Power Generation Conference, Beijing, China, 9-11 September 2013; pp. 1-4. [CrossRef]

14. Dudda, B.; Shin, D. Effect of nanoparticle dispersion on specific heat capacity of a binary nitrate salt eutectic for concentrated solar power applications. Int. J. Therm. Sci. 2013, 69, 37-42. [CrossRef]

15. Chieruzzi, M.; Cerritelli, G.F.; Miliozzi, A.; Kenny, J.M. Effect of nanoparticles on heat capacity of nanofluids based on molten salts as PCM for thermal energy storage. Nanoscale Res. Lett. 2013, 8, 448. [CrossRef] [PubMed]

16. Jo, B.; Banerjee, D. Enhanced Specific Heat Capacity of Molten Salt-Based Carbon Nanotubes Nanomaterials. J. Heat Transf. 2015, 137, 091013. [CrossRef]

17. Shin, D.; Banerjee, D. Enhanced Specific Heat Capacity of Nanomaterials Synthesized by Dispersing Silica Nanoparticles in Eutectic Mixtures. J. Heat Transf. 2013, 135, 032801. [CrossRef]

18. Seo, J.; Shin, D. Enhancement of specific heat of ternary nitrate $\left(\mathrm{LiNO}_{3}-\mathrm{NaNO}_{3}-\mathrm{KNO}_{3}\right)$ salt by doping with $\mathrm{SiO}_{2}$ nanoparticles for solar thermal energy storage. IET Micro Nano Lett. 2014, 9, 817-820. [CrossRef]

19. Schuller, M.; Shao, Q.; Lalk, T. Experimental investigation of the specific heat of a nitrate-alumina nanofluid for solar thermal energy storage systems. Int. J. Therm. Sci. 2015, 91, 142-145. [CrossRef]

20. Andreu-Cabedo, P.; Mondragon, R.; Hernandez, L.; Martinez-Cuenca, R.; Cabedo, L.; Julia, J.E. Increment of specific heat capacity of solar salt with $\mathrm{SiO}_{2}$ nanoparticles. Nanoscale Res. Lett. 2014, 9, 582. [CrossRef] [PubMed] 
21. Lasfargues, M.; Bell, A.; Ding, Y. In situ production of titanium dioxide nanoparticles in molten salt phase for thermal energy storage and heat-transfer fluid applications. J. Nanopart. Res. 2016, 18, 150. [CrossRef] [PubMed]

22. Lasfargues, M.; Geng, Q.; Cao, H.; Ding, Y. Mechanical Dispersion of Nanoparticles and Its Effect on the Specific Heat Capacity of Impure Binary Nitrate Salt Mixtures. Nanomaterials 2015, 5, 1136-1146. [CrossRef] [PubMed]

23. Shin, D.; Banerjee, D. Specific heat of nanofluids synthesized by dispersing alumina nanoparticles in alkali salt eutectic. Int. J. Heat Mass Transf. 2014, 74, 210-214. [CrossRef]

24. Harris, A.D.; Kalbus, L.H. Decomposition of copper(II) sulfate pentahydrate: A sequential gravimetric analysis. J. Chem. Educ. 1979, 56, 417. [CrossRef]

2017 by the authors. Licensee MDPI, Basel, Switzerland. This article is an open access article distributed under the terms and conditions of the Creative Commons Attribution (CC BY) license (http://creativecommons.org/licenses/by/4.0/). 